\title{
Response of T. Aman Rice (Oryza sativa L.) to S, Mg, Zn, B, Mo and Organic Amendments in Tista Meander Floodplain Soil
}

\author{
G. K. M. Mustafizur Rahman ${ }^{1 *}$, R. Ashrafi ${ }^{2}$, M. B. Hossain ${ }^{3}$ and M. L. Rahman ${ }^{4}$ \\ ${ }^{1}$ Department of Soil Science, Bangabandhu Sheikh Mujibur Rahman University, Gazipur-1706, Bangladesh \\ ${ }^{2}$ Department of Soil Science, Bangladesh Agricultural University, Mymensingh, Bangladesh \\ ${ }^{3}$ Bangladseh Institute of Nuclear Agriculture, Mymensingh, Bangladesh \\ ${ }^{4}$ Department of Soil Science, Dhaka University, Bangladesh \\ * Corresponding author
}

Received: 15 May 2007 Accepted: 15 July 2007

\begin{abstract}
A field experiment was conducted at the BINA sub-station of Tajhat, Rangpur in the Tista Meander Floodplain soil during aman season 2003 to study the response of T. aman rice to $\mathrm{S}, \mathrm{Mg}, \mathrm{Zn}, \mathrm{B}$, Mo and organic amendments. The experiment was laid-out in a randomized complete block design with nine treatments is with three replications as $\mathrm{T}_{1}$ : complete $(\mathrm{S}+\mathrm{Mg}+\mathrm{Zn}+\mathrm{B}+\mathrm{Mo}), \mathrm{T}_{2}$ : complete-S, $\mathrm{T}_{3}$ : complete-Mg, $\mathrm{T}_{4}$ : complete-Zn, $\mathrm{T}_{5}$ : complete-B, $\mathrm{T}_{6}$ : complete-Mo, $\mathrm{T}_{7}$ : cowdung @ 5 t/ha, $\mathrm{T}_{8}$ : poultry manure @ 5 t/ha and $\mathrm{T}_{9}$ : control. Nitrogen, phosphorus and potassium were applied in recommended doses as basal. The highest grain (3927 kg/ha) and straw (4472 kg/ha) yields were recorded with the application of poultry manure, followed by cowdung and complete $(\mathrm{S}+\mathrm{Mg}+\mathrm{Zn}+\mathrm{B}+\mathrm{Mo})$ treatment. The lowest yield was recorded in the control plot. The overall results indicate that application of organic amendments with NPK gave satisfactory yield of T. aman rice in the Tista Meander Floodplain Soil.
\end{abstract}

Keywords: Yield, organic amendments, rice.

\section{Introduction}

Bangladesh soils are depleted in many respects of essential nutrients mainly because of intensive cultivation without organic matter recycling. Fertilizers are indispensable for modern agriculture and are being responsible for about $50 \%$ of the total agricultural production (FRG, 1997). Howevwer, it is difficult to sustain crop production by using either chemical fertilizers or organic manures alone (Bair, 1990). The combined use of organic and inorganic fertilizers might be helpful for sustainable crop production and maintenance of soil fertility. Nambiar (1991) reported that integrated use of organic manure and chemical fertilizers would be quite promising not only for stability in production, but also for maintaining soil fertility status.
Before 1980's, deficiency of NPK was a major problem of Bangladesh soils, but thereafter deficiencies of $\mathrm{S}, \mathrm{Zn}$ and B were also frequently reported to be deficient(Islam and Hossain, 1993; Hoque and Jahiruddin, 1994; Jahiruddin et al., 1995). Thus, soil fertility has been gradually declining resulting stagnation yields of major crops of the country (Bhuiyan, 1995). Hence, an experiment was conducted to study the response of T. aman rice to applied S, Mg, Zn, B, Mo and organic amendments in Tista Meander Floodplain Soil.

\section{Materials and Methods}

The experiment was carried out at the BINA Substation, Tajhat and Rangpur during aman season of 2003. The soils belong to the agroecological zone "Tista Meander Floodplain Soil" having texture of 
sandy loam, pH 6.30, organic matter $1.24 \%$, total N $0.11 \%$, available P 2.44 ppm, exchangeable K 0.05 meq\%, available S $6.62 \mathrm{ppm}$, available B 0.17 ppm, available $\mathrm{Zn} 0.45 \mathrm{ppm}$, exchangeable $\mathrm{Mg}$ $1.37 \mathrm{meq} \%$, available Fe $31.92 \mathrm{ppm}$, available $\mathrm{Mn}$ $5.13 \mathrm{ppm}$ and available Mo $0.25 \mathrm{ppm}$.

T. aman rice cv. Binadhan- 4 was used as test crop. The experiment was laid out in a randomized complete block design with three replications. There were nine treatment combinations as $\mathrm{T}_{1}=$ complete $(\mathrm{S}+\mathrm{Mg}+\mathrm{Zn}+\mathrm{B}+\mathrm{Mo}) ; \quad \mathrm{T}_{2}=$ complete $-\mathrm{S} ; \mathrm{T}_{3}=$ complete $-\mathrm{Mg} ; \quad \mathrm{T}_{4}=$ complete $-\mathrm{Zn} ; \mathrm{T}_{5}=$ complete $-\mathrm{B} ; \mathrm{T}_{6}=$ complete $-\mathrm{Mo} ; \mathrm{T}_{7}=$ Cowdung (CD) @ 5 t/ha; $\mathrm{T}_{8}=$ Poultry Manure (PM) @ $5 \mathrm{t} / \mathrm{ha}$ and $\mathrm{T}_{9}=$ control. The unit plot size was $4 \times 3 \mathrm{~m}$. The distance between two unit plots and blocks were $0.3 \mathrm{~m}$ and $0.7 \mathrm{~m}$, respectively. $\mathrm{N}, \mathrm{P}, \mathrm{K}, \mathrm{S}, \mathrm{Mg}, \mathrm{Zn}, \mathrm{B}$, and $\mathrm{Mo}$ were used at the rate of $75,20,25,30,15,5,2$ and $1.5 \mathrm{~kg} / \mathrm{ha}$, respectively in the experiment and all the plots including control received NPK as basal dose. The sources of N, P, K, S, Mg, Zn, B, and Mo were urea, DAP, MP, gypsum, the magnesium oxide, zinc oxide, borax and ammonium molybdate, respectively. The amount of $\mathrm{N}$ contained in the DAP was adjusted with urea at the time of calculating the fertilizer. All the other fertilizers and 1/3 urea were applied at the time of final land preparation and rest of the urea was applied in two equal installments at maximum tillering stage and at panicle initiation stage of the crop. Cowdung and poultry manure were applied 15 days before planting. Twenty five days old seedlings were transplanted at 3 seedlings per hill a distance of $20 \times 20 \mathrm{~cm}$.

Standing water of approximately 5-6 cm was maintained in each pot throughout the growing period. All other intercultural operations were done whenever necessary and data on yield and yield contributing parameters were recorded at maturity of the crop. All the data were taken when the crop attained maturity. The yield contributing parameters such as plant height, panicle length, number of panicles per hill, and 1000-grain weight $(\mathrm{g})$ were collected from 10 (ten) randomly selected plants taken from each plot. Grain and straw yields were recorded plot- wise. The grain and straw yields were recorded on sundry basis. Grain yield was adjusted to 14 $\%$ moisture content. All chemical analysis for soil was done using the following methods:

The particle size analysis was done by hydrometer method as described by Piper (1966) and the textural class was determined by using the Marshall's triangular co-ordinate following USDA system and soil $\mathrm{pH}$ was determined by using Glass Electrode $\mathrm{pH}$ meter. The soil-water ratio was 1: 2.5 as described by Jackson (1973).

The organic carbon of the soil sample was determined by Walkley and Black (1965) wet oxidation method as outlined by Jackson (1973). The amount of soil organic matter was calculated by multiplying the percent value of organic carbon with Van Bemmelen factor, 1.73.

Total nitrogen content was determined following Micro Kjeldahl method as described by Jackson (1973). Total $\mathrm{N}$ in the soil was determined by Micro Kjeldahl method by digesting soil sample with $\mathrm{H}_{2} \mathrm{O}_{2}$ concentrated $\mathrm{H}_{2} \mathrm{SO}_{4}$ and catalyst mixture $\left(\mathrm{K}_{2} \mathrm{SO}_{4}: \mathrm{CuSO}_{4} \cdot 5 \mathrm{H}_{2} \mathrm{O}: \mathrm{Se}=10: 1: 0.1\right)$. Nitrogen in the digest was estimated by distillation with $40 \% \mathrm{NaOH}$ followed by titration of the distillate trapped in $\mathrm{H}_{3} \mathrm{BO}_{3}$ with $0.01 \mathrm{~N} \mathrm{H}_{2} \mathrm{SO}_{4}$ (Page et al., 1982).

Available $\mathrm{P}$ in the soil was extracted by shaking with $0.5 \mathrm{M} \mathrm{NaHCO}_{3}$ solution having $\mathrm{pH} 8.5$ following the method described by Olsen et al. (1954). The extracted $\mathrm{P}$ was then determined colorimetrically by $\mathrm{SnCl}_{2}$ reduction method at $660 \mathrm{~nm}$ wave length.

Exchangeable $\mathrm{K}$ and $\mathrm{Mg}$ were determined by extraction with $1 \mathrm{~N} \mathrm{NH}_{4} \mathrm{OAc}, \mathrm{pH} 7.0$ solution followed by measurement of extractable elements by atomic absorption spectrophotometer (Page et al., 1982).

Available $\mathrm{S}$ content in soil was determined by extracting soil sample with calcium phosphate $\left\{\mathrm{CaH}_{4}\left(\mathrm{PO}_{4}\right)\right\}$ as described by ASI (Agro Services International). The $\mathrm{S}$ content in the digest (extract) was determined by the acid seed and turbidimetric procedure improved by Hunter (1984). Available $\mathrm{Zn}, \mathrm{Fe}$ and $\mathrm{Mn}$ in soil were determined by DTPA extraction method. While 
B was determined by $0.01 \mathrm{M} \mathrm{CaCl}_{2} \cdot 2 \mathrm{H}_{2} \mathrm{O}$ extracting method. Besides, grain and straw samples were analyzed for $\mathrm{N}, \mathrm{P}, \mathrm{K}, \mathrm{S}, \mathrm{Mg}, \mathrm{Zn}$, $\mathrm{B}, \mathrm{Fe}$ and Mn using standard methods (Jackson, 1973; Page et al. 1982 and Hunter 1984).

The analyses of variance for different parameters were done following the principle of F-statistics and the mean results were compared using Duncan's Multiple Range Test (DMRT).

\section{Results and Discussion}

Plant height, panicle length and 1000-grain weight of $\mathrm{T}$. aman rice were not influenced by different treatment combinations except tillering (Table 1). However, the highest number of panicles/hill (7.40) was observed when poultry manure was applied $\left(\mathrm{T}_{8}\right)$. This was statistically identical with that of the treatments $T_{7}$ (cowdung), $\mathrm{T}_{2}$ (complete-S) and $\mathrm{T}_{1}$ (complete). The lowest number of tillers/hill (5.87) was observed in control $\left(\mathrm{T}_{9}\right)$ treatment. Similar results were also found by Kant and Kumar (1994).

Grain yield responded significantly to the application of $\mathrm{S}, \mathrm{Mg}, \mathrm{Zn}, \mathrm{B}$, Mo and organic amendments (Table 1). All the treatments gave significantly higher grain yield over control. The grain yield varied from 3408 to $3927 \mathrm{~kg} / \mathrm{ha}$. The highest grain yield of $3927 \mathrm{~kg} / \mathrm{ha}$ was given by the treatment $\mathrm{T}_{8}$ (Poultry Manure) which was $15.2 \%$ higher than that of control. The second highest grain yield of $3597 \mathrm{~kg} / \mathrm{ha}$ was observed in the treatment $T_{1}$ (comprising all the 5 added nutrients) and it was statistically identical with that of $\mathrm{T}_{7}$ (cowdung) and $\mathrm{T}_{5}$ (complete-B) treatments. In producing grain yield, the treatments could be ranked in order of $\mathrm{T}_{8}>\mathrm{T}_{1}>$ $\mathrm{T}_{7}>\mathrm{T}_{5}>\mathrm{T}_{3}>\mathrm{T}_{2}>\mathrm{T}_{6}>\mathrm{T}_{4}>\mathrm{T}_{9}$. This result is in agreement well with those reported by Karim (2001).

Straw yield was also significantly influenced by treatments (Table 1). The straw yields varied from 3916 to $4472 \mathrm{~kg} / \mathrm{ha}$. As in case of grain yield, the highest straw yield $(4472 \mathrm{~kg} / \mathrm{ha})$ was recorded in poultry manure treatment $\left(\mathrm{T}_{8}\right)$ which was significantly different from that of all other treatments. The second highest straw yield was obtained in $\mathrm{T}_{5}$ (complete $-\mathrm{B}$ ) treatment which was statistically similar to $T_{7}(C D)$ but significantly higher than that of other treatments. In producing straw yield, the treatments could be ranked in order of $\mathrm{T}_{8}>\mathrm{T}_{5}>\mathrm{T}_{7}>\mathrm{T}_{1}>\mathrm{T}_{6}>\mathrm{T}_{2}>\mathrm{T}_{3}>\mathrm{T}_{4}>\mathrm{T}_{9}$. Other workers (Rajput and Warsi, 1991) also reported that the application of organic manure and chemical fertilizers increased straw yield of rice.

Table 1. Effect of S, Mg, Zn, B, Mo and organic manures on yield and yield components of T. aman rice (Binadhan-4).

\begin{tabular}{lcccccc}
\hline \multicolumn{1}{c}{ Treatments } & $\begin{array}{c}\text { Plant } \\
\text { height } \\
(\mathrm{cm})\end{array}$ & $\begin{array}{c}\text { No. of } \\
\text { panicles/ } \\
\text { hill }\end{array}$ & $\begin{array}{c}\text { Panicle } \\
\text { Length } \\
(\mathrm{cm})\end{array}$ & $\begin{array}{c}1000 \\
\text { grain } \\
\text { weight }(\mathrm{g})\end{array}$ & $\begin{array}{c}\text { Grain } \\
\text { yield } \\
(\mathrm{kg} / \mathrm{ha})\end{array}$ & $\begin{array}{c}\text { Straw } \\
\text { yield } \\
(\mathrm{kg} / \mathrm{ha})\end{array}$ \\
\hline $\mathrm{T}_{1}=\mathrm{S}+\mathrm{Mg}+\mathrm{Zn}+\mathrm{B}+\mathrm{Mo}($ Complete $)$ & 100.4 & $6.90 \mathrm{abc}$ & 25.73 & 22.82 & $3597 \mathrm{~b}$ & $4085 \mathrm{c}$ \\
$\mathrm{T}_{2}=$ Complete $-\mathrm{S}$ & 99.67 & $6.80 \mathrm{abc}$ & 25.00 & 21.41 & $3441 \mathrm{~d}$ & $4044 \mathrm{~cd}$ \\
$\mathrm{~T}_{3}=$ Complete $-\mathrm{Mg}$ & 99.67 & $6.00 \mathrm{de}$ & 25.13 & 22.67 & $3519 \mathrm{c}$ & $3999 \mathrm{cde}$ \\
$\mathrm{T}_{4}=$ Complete $-\mathrm{Zn}$ & 101.1 & $6.33 \mathrm{cde}$ & 25.63 & 21.28 & $3411 \mathrm{~d}$ & $3971 \mathrm{de}$ \\
$\mathrm{T}_{5}=$ Complete $-\mathrm{B}$ & 100.2 & $6.73 \mathrm{bc}$ & 25.13 & 22.00 & $3555 \mathrm{bc}$ & $4238 \mathrm{~b}$ \\
$\mathrm{~T}_{6}=$ Complete $-\mathrm{Mo}$ & 98.93 & $6.60 \mathrm{bcd}$ & 26.00 & 21.00 & $3430 \mathrm{~d}$ & $4077 \mathrm{c}$ \\
$\mathrm{T}_{7}=$ Cowdung @ 5t/ha & 101.3 & $7.00 \mathrm{ab}$ & 26.33 & 23.55 & $3597 \mathrm{~b}$ & $4180 \mathrm{~b}$ \\
$\mathrm{~T}_{8}=$ Poultry Manure @5t/ha & 100.1 & $7.40 \mathrm{a}$ & 25.00 & 24.00 & $3927 \mathrm{a}$ & $4472 \mathrm{a}$ \\
$\mathrm{T}_{9}=$ Control & 98.07 & $5.87 \mathrm{e}$ & 24.97 & 20.33 & $3408 \mathrm{~d}$ & $3916 \mathrm{e}$ \\
$\mathrm{CV}$ (\%) & 4.89 & 5.03 & 4.54 & 7.83 & 4.87 & 3.19 \\
LSD $(0.05)$ & 4.997 & 0.5767 & 1.998 & 3.238 & 40.39 & 84.94 \\
\hline
\end{tabular}

The figures having common letter in a column are not significantly different by DMRT at $5 \%$ level. LSD $=$ Least Significant Difference, CV = Co-efficient of Variation 

Table 2. Effect of added nutrients on N, P, K, S, Mg, Zn and B uptake (Kg/ha) by grain and straw of T. aman rice (Binadhan-4).

\begin{tabular}{|c|c|c|c|c|c|c|c|c|c|c|c|c|c|c|}
\hline \multirow{2}{*}{$\begin{array}{c}\text { Treat } \\
\text { ments }\end{array}$} & \multicolumn{7}{|c|}{ Grain } & \multicolumn{7}{|c|}{ Straw } \\
\hline & $\mathrm{N}$ & $\mathrm{P}$ & $\mathrm{K}$ & $S$ & $\mathrm{Mg}$ & $\mathrm{Zn}$ & B & $\mathrm{N}$ & $\mathrm{P}$ & $\mathrm{K}$ & $S$ & $\mathrm{Mg}$ & $\mathrm{Zn}$ & B \\
\hline $\mathrm{T} 1$ & $28.32 \mathrm{bc}$ & 10.57 & $24.51 \mathrm{a}$ & $3.140 \mathrm{bc}$ & $6.004 \mathrm{a}$ & $0.085 \mathrm{a}$ & $0.057 \mathrm{a}$ & $17.14 \mathrm{c}$ & 6.602 & $76.17 \mathrm{c}$ & $5.140 \mathrm{a}$ & 8.495 & $0.290 \mathrm{ab}$ & $0.205 \mathrm{ab}$ \\
\hline $\mathrm{T} 2$ & $26.37 \mathrm{c}$ & 10.59 & $18.89 \mathrm{~cd}$ & $2.595 \mathrm{~d}$ & $5.458 \mathrm{~b}$ & $0.069 \mathrm{cde}$ & $0.048 \mathrm{~b}$ & $15.16 \mathrm{~d}$ & 7.388 & $47.49 \mathrm{~cd}$ & $3.702 \mathrm{bc}$ & 8.436 & $0.275 b c$ & $0.192 b c$ \\
\hline $\mathrm{T} 3$ & $26.50 \mathrm{c}$ & 11.27 & $22.18 \mathrm{ab}$ & $3.051 \mathrm{c}$ & $5.369 \mathrm{~b}$ & $0.072 \mathrm{bc}$ & $0.045 \mathrm{~b}$ & $16.84 \mathrm{c}$ & 6.914 & $70.45 \mathrm{e}$ & $5.130 \mathrm{a}$ & 7.300 & $0.283 \mathrm{ab}$ & $0.152 \mathrm{e}$ \\
\hline $\mathrm{T} 4$ & $26.12 \mathrm{c}$ & 10.43 & $19.35 \mathrm{~cd}$ & $2.934 \mathrm{c}$ & $5.469 \mathrm{~b}$ & $0.066 \mathrm{de}$ & $0.049 \mathrm{~b}$ & $17.76 \mathrm{c}$ & 6.646 & $73.01 \mathrm{de}$ & $4.666 \mathrm{ab}$ & 8.498 & $0.190 \mathrm{e}$ & $0.182 \mathrm{~cd}$ \\
\hline $\mathrm{T} 5$ & $26.18 \mathrm{c}$ & 11.19 & $19.69 \mathrm{c}$ & $2.820 \mathrm{~cd}$ & $5.573 \mathrm{~b}$ & $0.072 \mathrm{bcd}$ & $0.038 \mathrm{c}$ & $23.59 \mathrm{ab}$ & 8.237 & $70.31 \mathrm{e}$ & $5.139 \mathrm{a}$ & 8.609 & $0.296 \mathrm{a}$ & $0.134 \mathrm{f}$ \\
\hline T6 & $27.76 \mathrm{c}$ & 11.00 & $17.30 \mathrm{~d}$ & $2.927 \mathrm{c}$ & $6.004 \mathrm{a}$ & 0.070 bcde & $0.045 \mathrm{~b}$ & $22.03 \mathrm{~b}$ & 7.396 & $72.93 \mathrm{de}$ & $4.823 \mathrm{a}$ & 8.497 & $0.278 \mathrm{ab}$ & $0.171 \mathrm{~d}$ \\
\hline $\mathrm{T} 7$ & $30.96 \mathrm{ab}$ & 11.58 & $22.66 \mathrm{ab}$ & $3.716 \mathrm{a}$ & $5.662 \mathrm{~b}$ & $0.076 \mathrm{~b}$ & $0.058 \mathrm{a}$ & $22.16 \mathrm{~b}$ & 7.986 & $79.03 \mathrm{~b}$ & $5.013 \mathrm{a}$ & 7.906 & $0.240 \mathrm{~d}$ & $0.215 \mathrm{a}$ \\
\hline $\mathrm{T} 8$ & $31.83 \mathrm{a}$ & 12.41 & $23.97 \mathrm{a}$ & $3.416 \mathrm{ab}$ & $6.161 \mathrm{a}$ & $0.082 \mathrm{a}$ & $0.056 \mathrm{a}$ & $24.38 \mathrm{a}$ & 9.080 & $82.26 \mathrm{a}$ & $5.013 \mathrm{a}$ & 8.695 & $0.259 \mathrm{c}$ & $0.143 \mathrm{ef}$ \\
\hline T9 & $25.47 \mathrm{c}$ & 11.36 & $20.79 \mathrm{bc}$ & $2.498 \mathrm{~d}$ & $4.925 \mathrm{c}$ & $0.065 \mathrm{e}$ & $0.037 \mathrm{c}$ & $14.02 \mathrm{~d}$ & 7.203 & $74.70 \mathrm{~cd}$ & $3.325 \mathrm{c}$ & 7.212 & $0.184 \mathrm{e}$ & $0.101 \mathrm{~g}$ \\
\hline $\mathrm{CV}(\%)$ & 4.20 & 7.83 & 5.87 & 5.92 & 5.64 & 3.41 & 5.26 & 4.67 & 15.85 & 4.52 & 12.72 & 9.60 & 7.18 & 6.56 \\
\hline $\begin{array}{l}\text { LSD } \\
(0.05)\end{array}$ & 2.863 & 1.513 & 2.158 & 0.310 & 0.295 & 0.006 & 0.006 & 1. 569 & 2.056 & 2.670 & 1.025 & 1.360 & 0.017 & 0.013 \\
\hline
\end{tabular}

N. B.: The figures having common letter in a column are not significantly different by DMRT at $5 \%$ level. LSD = Least Significant Difference 

Nutrient uptake by rice grain and straw were significantly influenced by the treatments (Table 2 ). The highest uptake of all the nutrients by rice was observed in $\mathrm{T}_{8}$ (Poultry Manure) treatment except for $\mathrm{S}$ in $\mathrm{T}_{7}$ treatment (cowdung). The lowest $(2.498 \mathrm{~kg} / \mathrm{ha}) \mathrm{S}$ uptake by rice grain was found in $T_{9}$ (control) which was statistically identical to $\mathrm{T}_{2}$ (complete-S) treatment. The results indicate that $S$ uptake in rice grain increased with the application of cowdung plus NPK fertilizer. The findings of Wankhade et al, (1996) are in good agreement with this study. Those workers found that application of macro nutrients markedly increased their respective concentration and uptake by the crops.

Zinc uptake by grains and straw of $\mathrm{T}$. aman rice was significantly influenced by addition of other nutrients (Table 2). The highest $\mathrm{Zn}$ uptake was observed in $T_{1}$ treatment which was statistically similar to that found in $\mathrm{T}_{8}(\mathrm{PM})$ treatment. The lowest $\mathrm{Zn}$ uptake was observed in $\mathrm{T}_{9}$ treatment which was statistically different from all other treatments. The highest $\mathrm{B}$ uptake by rice grain and straw was observed in $\mathrm{T}_{7}$ treatment which was statistically similar to that found in $T_{1}$ (complete) and $\mathrm{T}_{8}(\mathrm{PM})$ treatments. It might be due to $\mathrm{B}$ fertilization as well as contribution of $\mathrm{B}$ from $\mathrm{CD}$ and $\mathrm{PM}$. The lowest $\mathrm{B}$ uptake by rice plant was observed in $\mathrm{T}_{9}$ (control) treatment which was statistically similar to that found in $T_{5}$ (complete-B). The observation of Wankhade et al. (1996) was very similar to the present findings. They observed higher uptake of $\mathrm{Zn}$ and $B$ with the application of single nutrient or with other micronutrients.

\section{Conclusions}

It may be concluded that for efficient $\mathrm{T}$. aman rice production in this soil, an application of secondary nutrients and micronutrients with $\mathrm{N}$, $\mathrm{P}, \mathrm{K}$ is essential but among the treatments the highest yield (straw 4472 and grain $3927 \mathrm{~kg} / \mathrm{ha}$ ) was observed in the treatment $\left(\mathrm{T}_{8}\right)$ where poultry manure (@ 5 t/ha) with NPK was applied.

\section{References}

Bair, N. 1990. Characterization of the environment for sustainable agriculture in semi-arid tropics. Proc. of the International Symposium on Sustainable Agriculture, Issues, Perspectives and Prospects in Semi-Arid Tropics (Ed.), R.P. Singh. Indian Society of Agronomy, 1: $90-128$

Bhuiyan, N. I. 1995. Intensive cropping and soil nutrient balance in Bangladesh in improving soil management for intensive cropping in the tropics and sub-tropics. Proc. of International Congress of Communication IV. Dec. 1-3, 1992 Dhaka, Bangladesh. p. 11-14.

FRG (Fertilizer Recommendation Guide), 1997. Bangladesh Agricultural Research Council (BARC). Soils Publication No. 41. Farmgate, Dhaka, p.25-184.

Hunter, A.H. 1984. Soil Fertility Analytical Services in Bangladesh Consultancy Report, BARC. Dhaka.

Hoque, M.S. and Jahiruddin, M.1994. Effect of single and multiple application of sulphur, and zinc in a continuous rice cropping pattern. Indian Journal of Agriculture Research, 28(1): 9-14.

Islam, M.R. and Hossain, A. 1993. Influence of additive nutrients on the yield of BR11 rice, Thai Journal of Agricultural Science, 26 : 195-199.

Jahiruddin, M., Ali, M. S., Hossain, M. A, Ahmed, M. U. and Hoque, M. M. 1995. Effect of boron on grain set, yield and some other parameters of wheat cultivars. Bangladesh Journal of Agricultural Science, 22: 179-184.

Jackson, M. L. 1973. Soil Chemical Analysis. Prentice Hall of India Private limited, New Delhi, India.

Kant, S and Kumar, R. 1994. A comparative study of the effect of four soil amendments on the uptake of Fe, Mn and yield of rice in salt affected soil. Indian 
Journal of Agricultural Chemistry, 27 (283): 59-70.

Karim, R. M. 2001. Effect of magnesium, sulphur, zinc boron and molybdenum on BRRIdhan-30. M. S. Thesis. Dept. of Soil Science. Bangladesh Agricultural University, Mymensingh.

Nambiar, K. K. M. 1991. Long-term fertility effects on wheat productivity. Wheat for the nontraditional warm areas: A proceedings of the International Conference. Mexico DF (Mexico). CIMMYT. pp. 516-521.

Olsen, S. R.; Cole, C.V.; Watanabe, F. S. and Dean, L. A. 1954. Estimation of available phosphorus in soil by extraction with Sodium bicarbonate. U. S. Department of Agriculture: p. 939.

Page, A. L.; Miller, R. .H. and Keeney, D. R. 1982. Methods of soil Analysis Part 2. $2^{\text {nd }}$ Ed. American Society of Agronomy. Medison Wisconsin, USA.
Piper, C. S. 1966. Soil and Plant Analysis. Hans Publishers, Bombay, India.

Rajput, A. L. and Warsi, A. S. 1991. Contribution of organic materials to nitrogen economy in rice (Oryza sativa) production. Indian Journal of Agronomy, 36(3): 455-456.

Walkley, A. and Black, I.A. 1965. An examination of the Degtiareff method for determining soil organic matter and a proposed modification of the chromic acid titration method. Soil Science. 37: 29-38.

Wankhade, S.G.; Dakhore, R.C.; Wanjari S.S.; Pafil, D.B.; Potdukhe, N.R.and Ingle, R.W.1996. Response of crops to micronutrients Indian. Journal of Agriculture Research. 30(3-4): 164-168. 